\title{
Sediment movement through riparian vegetation under sim- ulated rainfall and overland flow
}

\author{
ROBERT A. PEARCE, M. J. TRLICA, WAYNE C. LEININGER, DARYL E. MERGEN, AND GARY FRASIER
}

Authors are EnviroCounsel Consulting, P.O. Box 54, Big Pine, California 93513; professor, associate professor, Rangeland Ecosystem Science Department, Colorado State University, Fort Collins, Colo 80523; plant ecologist, Westem Ecological Resource, 711 Walnut, Boulder, Colo 80306; research hydraulic engineer, Agricultural Research Service-Rangeland Resources Research Unit, 1701 Center, Fort Collins, Colo 80526. At the time of the research the first and fourth authors were graduate research assistants, Rangeland Ecosystem Science Department, Colorado State University,.

\begin{abstract}
A 2-year rainfall simulation study was conducted to evaluate the effectiveness of riparian vegetation to reduce sediment movement. Three vegetation height treatments [clipped to the soil surface, $10 \mathrm{~cm}$ height, and undisturbed (unclipped)] were evaluated in 2 montane riparian vegetation communities in northern Colorado. One community was a tufted hairgrass (Deschampsia caespitosa (L.) Beauv.), cinquefoil (Potentilla gracilis Dougl. ex Hook), Kentucky bluegrass (Poa pratensis L.), and sedge (Carex spp.) association. The other community was dominated by beaked sedge (Carex rostrata Stokes) and water sedge (Carex aquatilis Wahl.). Water was sprayed on plots $(3 \mathrm{~m} \times 10 \mathrm{~m})$ at a rate of $60 \mathrm{~mm}$ hour ${ }^{-1}$ with a rainfall simulator, while overland now containing sediment was introduced at the upper end of the plots at a rate of $25 \mathrm{~mm}$ hour-1. Two sediment sources were evaluated. In the first year's studies the sediment was derived from an upland soil. The second year a fine silica sediment was used. Thirty $\mathrm{kg}$ of sediment was added to each plot. The first of 2 experiments was concerned with movement of sand particles greater than $200 \mu \mathrm{m}$. The second experiment was designed to evaluate the quantity of 5 particle size classes (2-10, 10-30, $30-50,50-100$, and 100-200 $\mathrm{mm}$ ) contained in sediment traps at 60,120 , and $180 \mathrm{~cm}$ downslope from the upslope border of the simulator plots.

Results of the first experiment showed a significant increase in sand movement downslope when vegetation was clipped to the soil surface compared with undisturbed vegetation. In the second experiment, most significant differences in movement for finer particles occurred in the $2-10 \mu \mathrm{m}$ and $10-30 \mu \mathrm{m}$ particle ranges. A smaller percentage of particles in the $2-10 \mu \mathrm{m}$ range was present in sediment traps at all 3 distances downslope when vegetation was clipped to the soil surface, as these smaller particles stayed in suspension. Increased vegetation height resulted in a significantly smaller percentage of the $10-30 \mu \mathrm{m}$ particle size range present at $120 \mathrm{~cm}$ distance. This study showed that additional variables (\% surface vegetation cover, aboveground biomass, \% shrubs, surface roughness coefficient, soil texture of introduced sediment, \% bare ground, distance downslope, vegetation density, grass spp., and sedge spp.), besides vegetation
\end{abstract}

Research was funded by USDA Competitive Grant-Water Quality Program, Colorado State University Agricultural Experiment Station, and USDA Agricultural Research Service.

Manuscript accepted 17 Aug. 1997. height, influenced sediment movement. Land managers should understand that when they manage ecosystems for a single factor, such as vegetation height, they cannot address complex issues such as sediment particle detachment, movement and filtration.

Key Words: Stubble height, erosion, transport capacity, sediment filtration, particle size distribution, nonpoint source pollution

\section{Resumen}

Se condujo una investigación de simulación de lluvia durante dos años para evaluar la eficacia de la vegetación ribereña para la reducción del movimiento de sedimento. Se usó una simuladora de lluvia con botalónes rotatorios para evaluar tres tratamientos con alturas vegetativas diferentes (el control, el rastrojo con altura de $10-\mathrm{cm}$, y la vegetación tijerada hasta eloesuelo) en dos communidades vegetativas mountañosas ribereñas del norte de Colorado. Se compusó una communidad de hierba copetuda (Deschampsia caespitosa (L.) Beauv.), cinquefoil (Potentilla gracilis Dougl. ex Hook), Kentucky bluegrass (Poa pratensis L.), y juncia (Carex. spp.). La otra comunidad fue dominada por juncia picuda (Carex rostrata Stokes) y juncia acuática (Cares aquatilis Whal.). La simuladora de lluvia roció agua sobre las parcelas (3 $x$ 10) a razón de $60 \mathrm{~mm}^{\text {hora }}{ }^{-1}$. Mientras desde cuesta arriba se introdujo a las parcelas agua orriente por tierra conteniendo a razón de $25 \mathrm{~mm}$ hora $^{-1}$. Se evaluó dos fuentes de sedimento. En el primer año, el sedimento vino de la tierra que estaba cuesta arriba de la parcela. En eloesegundo año se usó sedimento de sílice fina. Se aplicaron trienta kilogramos de sedimento a cadacepurcela. La primera investigación analizó el movimiento de partículas de arena más grande que $200 \mu \mathrm{m}$. La segunda investigación evaluó la cantidad de particulas en cinco clases de tamaño (2 -10, 10-30, $30-50,50-100$, y 100-200 $\mu \mathrm{m}$ ) acumulada en trampas de sedimento colocadas de la cumbre 60,120, y $180 \mathrm{~cm}$ cuesta abajo de cada parcela.

Los resultos de la primera investigación indicaron un aumento significativo de movimiento de arena cuesta abajo cuando vegetación fue tijerad hasta el suelo, comparado contra vegetación. En la segunda investigación, las differencias más significativas ocurrieron con las partículas finas de las clases de 2-10 $\mu \mathrm{m}$ y 10-30 $\mu \mathrm{m}$. Cuando la vegetación fue tijer hasta el suelo los porcentajes de partículas finas de la clase de 2-10 $\mu \mathrm{m}$ en 
las trampas de sedimento en las tres distancias fueron menores, porque estas partículas pequeñas quedaron suspendidas. Los aumentos de altura vegetativa resultaron en porcentajes significativamente reducidos en la clase de 10-30 $\mu \mathrm{m}$ a la distancia de $120 \mathrm{~cm}$. Esta investigación demostró que, aparte de altura vegetativa, variables adicionales (i.e. el porcentaje de la superficie cubierta poræevegetación, la masa bio lógica sobre la superficie de la tierra, el porcentaje de arbustos, el coeficiente de aspereza de la superficie, la clasificación textural del sedimento introducido, porcentaje de tierra descubierta, la distancia cuesta abajo, la densidad de la vegetaci ón, y las especies de hierba y juncia) influyen en el movimiento de sedimento. Los administradores de tierra deben comprender que cuando manejan los ecosistemas considerando un solo factor, como altura vegetativa, no pueden enfrentar temas complejos como desprendimiento, movimiento, filtración de partículas.

A major problem associated with heavy livestock grazing adjacent to or in riparian areas is the potential for sediment movement to streams from upland runoff (Kauffman and Krueger 1984). Increased stream sediment may negatively influence fish habitat and water quality (Rinne 1990, Platts 1991, Kondolf 1994). To address problems related to runoff and water quality in riparian areas, the U.S. Forest Service has developed minimum stubble height guidelines to assure that sediment will be filtered from runoff before reaching streams (Clary and Webster 1990). Stubble height is an easy variable to monitor, but its suitability as a guideline for sediment filtration has not been thoroughly evaluated.

Only a few studies that related runoff and sediment transport with vegetation characteristics have included stubble height data (Khan et al. 1988; Simanton et al. 1991; Abt et al. 1992, 1993; Clary et al. 1996). In the Khan et al. (1988) and Simanton et al. (1991) studies, stubble height data did not represent effective management methods to reduce sediment movement, or were used primarily to represent changes in canopy cover. In the Abt et al. (1992, 1993) and Clary et al. (1996) study, stubble height influence on sediment entrapment was evaluated in a simulated meandering stream where deep flow water covered all vegetation. This is different from our study that evaluated stubble height influence on sediment movement under shallow overland flow. In all these studies sediment movement within vegetation was not evaluated, but instead sediment filtration was measured.

Most previous research has focused on the influence of vegetation characteristics (i.e., distribution of vegetation, litter, and other variables) on sediment loss from uplands (Kauffman et al. 1983; Kauffman and Krueger 1984; McCalla et al. 1984; Warren et al. 1986; Thurow et al. 1988; Rogers and Schumm 1991). Specifically, there has been no research in riparian zones on vegetation cover, height, and other factors that influence overland sediment movement by particle size.

The influence of vegetation characteristics in riparian buffer zones on sediment movement, by different particle size classes, was evaluated in this study using a rotating boom rainfall simulator. It was hypothesized that stubble height alone would not be an effective measure of vegetation influence on sediment movement in riparian zones. Additionally, it was hypothesized that vegetation characteristics, soil surface characteristics, and particle size distribution of sediment carried in overland flow all influenced sediment movement in riparian zones. Mcasurements of several soil surface variables and vegetation characteristics as they affect sediment movement should provide better information about sediment transport and deposition in riparian ecosystems.

\section{Methods}

\section{Study Site}

The experiments were conducted during the summers of 1993 and 1994 in the riparian zone along Sheep Creek in the Roosevelt National Forest. Sheep Creek is located about $80 \mathrm{~km}$ northwest of Fort Collins, Colo. Elevation at the study sites is $2,500 \mathrm{~m}$.

Studies were conducted each year in the same 2 riparian vegetation communities. The 2 communities were: 1) a grass complex made up of tufted hairgrass (Deschampsia caespitosa (L.) Beauv., cinquefoil (Potentilla gracilis Dougl. ex Hook), Kentucky bluegrass (Poa pratensis L.), and sedge (Carex spp.) vegetation complex, and 2) a sedge community comprised of primarily beaked sedge (Carex rostrata Stokes) and water sedge (Carex aquatilis Wahl.).

The Naz soil series dominates the Sheep Creek region. These are deep, well drained soils formed from granitic parent material. Soils in the riparian zones are primarily $\mathrm{Naz} 70$, with 3 to $25 \%$ slopes. Texture of the series is sandy to clay loam and the soils are classified as coarse loamy pachic cryoborols. The surface layer is an A horizon ranging from 20 to $80 \mathrm{~cm}$ thick having dark to gray-brown color (USDA 1980, Noor 1990).

\section{Plot Installation and Simulator Run}

Water was applied with a 'Swanson type' large rotating boom rainfall simulator situated over paired $3 \mathrm{~m} \times 10 \mathrm{~m}$ plots as outlined by Laflen et al. (1991)(Fig. 1). Metal sheets (15 cm high) were driven $6 \mathrm{~cm}$ into the ground on the sides and upslope end of each plot (Simanton et al. 1991). Runoff and sediment that reached the downslope end of a plot flowed into a collection trough and was directed into a super critical depth flume. Water depths in the flume were recorded at 1 min intervals using a bubble meter flow transducer. Each depth measurement was converted to a runoff volume rate. The design water application rate was $60 \mathrm{~mm}$ hour $^{-1}$. This application rate was not intended to reproduce naturally occurring rain storms, but instead was chosen for the

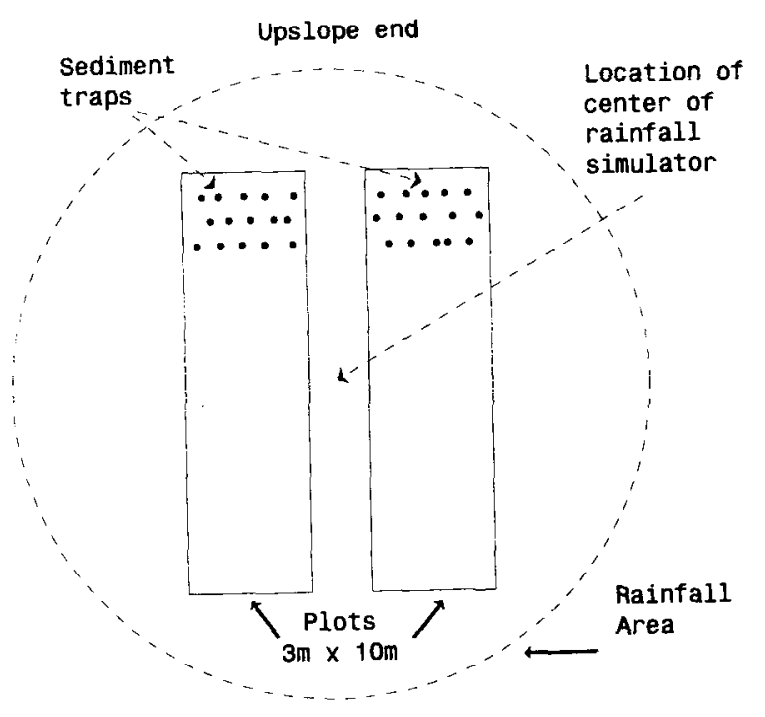

Fig. 1. Layout of plots for Sheep Creek rainfall simulations. Diagram shows location of plots in relation to rainfall simulator and location of sediment traps. 
ability to move sediment. There were some minor fluctuations resulting from wind and water pump inconsistencies. Therefore, the actual rate of water application was measured with a rain gauge equipped with a bubble gauge depth indicator located between the paired plots. Water application recordings were made at 1 min intervals.

To precondition soil moisture, water was sprayed with the simulator at the design $60 \mathrm{~mm}^{-1}$ hour ${ }^{-1}$ (no introduced overland flow) until equilibrium runoff was achieved from both plots. This precondition rainfall application was applied up to a maximum run time of $60 \mathrm{~min}$ in a few instances where equilibrium runoff was not attained. The preconditioning was followed by a 30 min rest period to allow the infiltrated water to partially equilibrate in the upper layer of the soil profile. The simulator was restarted following the rest period, and rainfall was added to the sitc at a rate of approximately $60 \mathrm{~mm}^{-1}$ hour ${ }^{-1}$.

Concurrent with the second rainfall application was the introduction of uniform overland flow at the upper end of each plot at the rate of approximately $25 \mathrm{~mm}$ hour ${ }^{-1}$ to simulate runoff from an upland area into the riparian zone (total water application for each simulation was $85 \mathrm{~mm}^{-1}$ hour $^{-1}$ and a run time of $30 \mathrm{~min}$ ). A wood framed platform $3.0 \mathrm{~m} \times 0.60 \mathrm{~m}$ covered with sheet metal was placed at the upslope end of each plot at approximately a $6 \%$ slope. Stationed directly above the platform at a distance of 0.60 m was a spray bar with 5 nozzles that sprayed water down onto the platform. The water to the spray nozzles was controlled through a pressure regulator. Actual rates were determined by volumetric calibration of each nozzle during the run. Water on the sheet metal covered platform flowed onto the upper edge of the plot as uniform overland flow.

\section{Sediment Introduction}

Thirty $\mathrm{kg}$ of sediment was introduced to each plot during each simulation run. The $30 \mathrm{~kg}$ level was selected following practice simulation runs where $15 \mathrm{~kg}\left(5,000 \mathrm{~kg} \mathrm{ha}^{-1}\right)$ of sediment as added to each plot that represented actual levels of sediment that might be expected to reach riparian areas from upland sites in overland flow [Buckhouse and Mattison 1980 (4,166 kg ha-1); Buckhouse and Gaither $\left.1982\left(6,743 \mathrm{~kg} \mathrm{ha}^{-1}\right)\right]$. However, little or no sediment was measured in the runoff with the $15 \mathrm{~kg}$ levels of added sediment, therefore, the practice level of introduced sediment was doubled to exceed the sediment filtration capacity of the vegetation. Total required sediment per plot was weighed and divided into 10 equal quantities, placed in plastic bags, and applied at 3 min intervals to the overland flow at the top of the plots after equilibrium flow (runoff from rainfall and overland flow) had been achieved.

The sediment for the first year (1993) simulations, was obtained from an upland site near the study area. The soil, a sandy loam, was sieved through $3 \mathrm{~mm}$ screen. Particle size distribution was $52.6 \%$ sand $(50-2000 \mu \mathrm{m}), 31.2 \%$ silt $(2-50 \mu \mathrm{m})$, and $16.2 \%$ clay (less than $2 \mu \mathrm{m}$ ).

The sediment for the second year (1994) study was a combination of 2 commercial ground silica products. The first product was SIL-CO-SIL ${ }^{\circledR} 250$, the second was MIN-U-SIL ${ }^{\circledR} 5$. These 2 products were mixed by weight as $60 \%$ SIL-CO-SIL ${ }^{\circledR} 250$ and $40 \%$ MIN-U-SIL ${ }^{\circledR}$ 5. The resultant particle size distribution was: $31.6 \%$ very fine sand (greater than $50 \mu \mathrm{m}), 41.8 \%$ silt $(2-50$ $\mu \mathrm{m}$ ), and $26.6 \%$ clay (less than $2 \mu \mathrm{m}$ ). This material was selected so that more sediment might be detected farther downslope.

\section{Treatments and Measurements}

Three vegetation height treatments (i.e., stubble heights) were evaluated in both vegetation communities. Height treatments were: clipping vegetation to the soil surface, clipping vegetation to $10 \mathrm{~cm}$, and a control where undisturbed vegetation height was maintained (1993 mean height $33 \mathrm{~cm}, 1994$ mean height $39 \mathrm{~cm}$ ). Vegetation was cut with a mower on the clipped plots and the clipped material was bagged and removed from the plots. Plots clipped to the soil surface were also vacuumed with a commercial shop vacuum to remove all litter from the soil surface. Both plots (i.e., pairs) for a simulation run had the same clipping treatment. Clipping treatments were randomly assigned to each experimental site (paired plots). The same plots were assigned to the same vegetation heights in 1993 and in 1994. Eight plots of each vegetation height treatment were evaluated each year ( 24 plots each year)

Vegetation surface cover, vegetation canopy cover, and species composition for the plots were determined by point frame methodology (100 points per plot) (Platts et al. 1987, Bonham 1989). Vegetation stem density (no. $\mathrm{m}^{-2}$ ) was determined by counting individual plants in a $\left(1 / 8 \mathrm{~m}^{2}\right)$ circular frame at 3 random locations within each plot. Standard surveying techniques were used to calculate plot slope.

Vegetation biomass was measured by clipping vegetation within a $\left(1 / 8 \mathrm{~m}^{2}\right)$ circular frame to ground level at 3 locations in each plot. Clipped material was placed in preweighed paper bags and dried in a forced air oven at $50^{\circ} \mathrm{C}$ for 3 days, then reweighed, and dry weight of vegetation determined as $\mathrm{g} \mathrm{m}^{-2}$.

Thirty-three plant species (both communities combined) were recorded within the simulation plots. For analysis purposes, species were characterized as either: sedge, grass, rush, forb or shrub.

Soil surface roughness was measured with an elevation table described by Linse (1992). The elevation table was used to measure surface roughness within a $0.6 \times 2 \mathrm{~m}$ area on each plot. Elevation of 100 points was taken in the center of the upslope portion of the plots. The standard deviation for 100 points (roughness coefficient) in each plot was calculated and used as a soil surfacc characteristic to evaluate the influence of surface roughness on sediment movement.

Soil texture for surface soil from each plot was determined at the Crops Research Laboratory, Agricultural Research Service, Fort Collins, Colo. Soil samples were first dried at $109^{\circ} \mathrm{C}$ for 40 hours to remove moisture, then the samples were ashed at $550^{\circ} \mathrm{C}$ for 5 hours (Storer 1984, Klute 1986), followed by the hydrometer analysis (Allen 1990).

\section{Sediment Movement}

Two experiments were conducted to evaluate sediment movement within riparian vegetation. Both experiments were conducted in all the plots. The first experiment was conducted to evaluate coarse particle (primarily $>200.0 \mu \mathrm{m}$, medium to coarse sand classifications) movement downslope from the upper border of runoff plots. Following a rainfall simulator run, the distance the sand moved downslope was measured at $5 \mathrm{~cm}$ intervals across the width of each plot. Mean travel distances were compared among plots to determine if differences in sand movement had occurred as a result of treatment differences.

The second experiment was used to evaluate particle movement and filtration at $60 \mathrm{~cm}, 120 \mathrm{~cm}$, and $180 \mathrm{~cm}$ downslope from the 
upper border of runoff plots. Small sediment traps, placed in 3 rows at $60 \mathrm{~cm}$ intervals downslope from the upper border of each plot, were used to evaluate deposition of 5 particle size class categories. Sediment traps were $6.6 \mathrm{~cm}$ in diameter at the top and 7.3 $\mathrm{cm}$ tall. Five sediment traps were placed (random spacing between traps) within each row (Fig. 1) with the top of the trap at soil surface level. Therefore, sediment was deposited in the trap as runoff passed over the trap. Literature on sediment traps of similar size could not be found, however, larger traps have been evaluated as a method to determine sediment movement on hill slopes (Wells and Wohlgemuth 1987).

The 5 particle size classifications in the second experiment were: 1) 2-10 $\mu \mathrm{m}, 2$ ) $10-30 \mu \mathrm{m}, 3)$ 30-50 $\mu \mathrm{m}, 4) 50-100 \mu \mathrm{m}$, and 5) $100-200 \mu \mathrm{m}$. Therefore, 3 particle size ranges within the silt $(2.0-50.0 \mu \mathrm{m})$ soil texture classification, and 2 within the fine sand (50.0-200.0 $\mu \mathrm{m})$ texture classification were analyzed. Shorter ranges in the silt particle size classes were chosen because most of the transported sediment was in the fine particle classes. All sediment contained in traps within a row, for each plot, was composited and the percentage of each particle size class present by row was used in data analysis.

A Met One ${ }^{\circledR}$ Model 25 batch sampler was used to analyze the size distribution of the sediment obtained from the traps. The Met One ${ }^{\circledR}$ is a liquid borne particle counter that utilizes a laser light blocking sensor (Allen 1990). Composite samples from 1 row of sediment traps contained less than $1 \mathrm{~g}$ of sediment in some instances. Thus, traditional methods for particle size distribution, such as hydrometer analysis, could not be utilized. A random sample of sediment was taken from each composited sample from each row $(60,120,180 \mathrm{~cm}$ distances $)$, mixed with filtered water, and analyzed with the Met One ${ }^{\circledR}$. Three $15 \mathrm{ml}$ subsamples were analyzed for each row of sediment traps to give 3 particle size distributions for each of the 5 size classes. Mean particle size for the 3 subsamples was used to determine if differences occurred among distances downslope $(60,120,180 \mathrm{~cm})$, among plots, and vegetation treatments.

Results for the particle size distribution included only relative distribution among particle size classes within the 2-200 $\mu \mathrm{m}$ range. The Met One ${ }^{\circledR}$ has limited size ranges available for analysis. Therefore, particles less than $2 \mu \mathrm{m}$ and greater than $200 \mu \mathrm{m}$ were not determined. Particles less than $2 \mu \mathrm{m}$ were likely in suspension and not filtered out by vegetation. Most particles greater than $200 \mu \mathrm{m}$ were not likely transported to the $60 \mathrm{~cm}$ distance, as evident by the sand particle deposition in the first experiment.

\section{Statistical Design}

The statistical design for sediment movement was a repeated measures split-split plot with factorial arrangement of treatments (Steel and Torrie 1980). The study treatments were: 1) 3 vegetation heights (zero, $10 \mathrm{~cm}$, and natural (unclipped) vegetation height) 2) 2 vegetation communities (sedge and a grass complex), and 3) 2 types of introduced sediment (sandy loam soil and silica material). Distance downslope (row) was a factor in the second experiment. Stubble height within plots at a site was a controllable factor, with vegetation cover, vegetation density, litter cover, species composition, surface roughness, bare ground, slope, soil texture, and rock cover as measurable factors. The experimental design for the vegetation communities and plot location was identical for both years. Therefore, 24 plots $(3 \mathrm{~m}$ $\times 10 \mathrm{~m}$ ) were evaluated each year of the study.

Multiple linear regression, analysis of variance (ANOVA)
(Steel and Torrie 1980), and multivariate analysis of variance (MANOVA)(Johnson and Wichern 1992) were used to determine relationships among vegetation heights, vegetation communities, distances downslope, and sediment types on sediment movement. A forward selection process was utilized to determine the variables to include in the regression model for the coarse particle movement and the sediment trap data. Data were analyzed using SAS $^{\circledR}$ for Windows ${ }^{\circledR}$ (SAS $\left.^{\circledR} 1993\right)$.

\section{Results and Discussion}

\section{Experiment 1: Sand Movement}

An ANOVA indicated that a significant 3-way interaction existed for vegetation community, vegetation height, and sediment type ( $P=0.03$ ). A least significant difference (LSD) procedure was applied to interaction means to determine where significant differences existed (Steel and Torrie 1980, Hoppe 1993).

Significant differences in sand movement downslope occurred among vegetation heights within the grass complex with Sheep Creek sediment, and the grass complex with silica sediment. Both sediment types had more sand movement downslope in the clipped to the soil surface treatment than for either the $10 \mathrm{~cm}$ or natural height vegetation treatment (Fig. 2). There was no significant difference in sand movement between the $10 \mathrm{~cm}$ vegetation height and the natural height treatments in the grass community. Sand particles went farther downslope in the sedge community with Sheep Creek sediment for the $0 \mathrm{~cm}$ and $10 \mathrm{~cm}$ vegetation height when compared with the natural vegetation height. When silica sediment was used in the sedge community, the greatest sand movement downslope occurred in the clipped to the soil surface treatment followed by the $10 \mathrm{~cm}$ height treatment (Fig. 2).

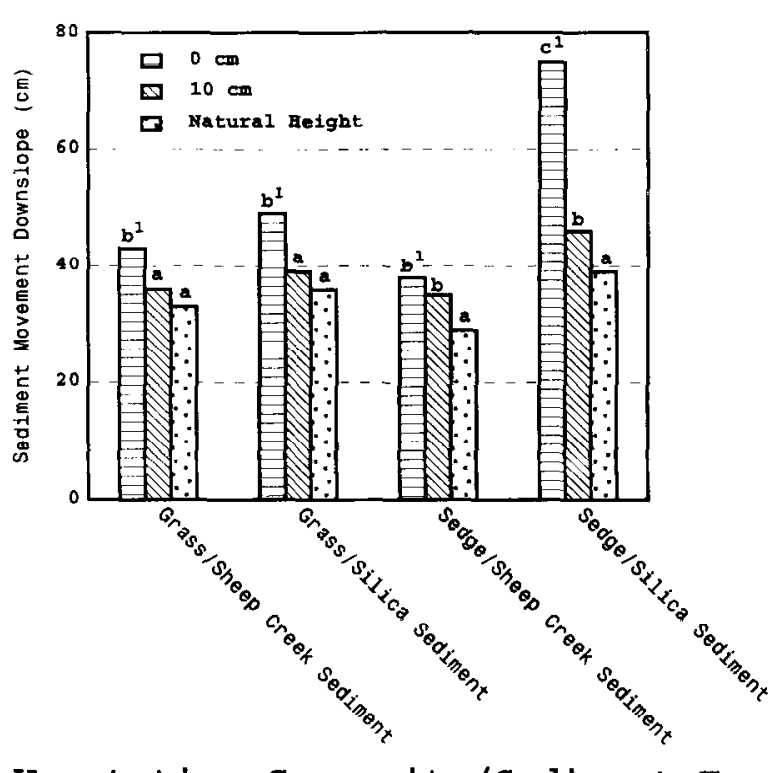

vegetation Community/sediment Type

Fig. 2. Interaction between vegetation community, sediment type and vegetation height for sediment movement downslope. ${ }^{1}$ Means in a bar cluster, by vegetation community/sediment type, with the same letter are not significantly different $(P<0.05)$. 
Differences among vegetation height treatment and sand movement downslope can be explained in part by the amount of vegetation cover in vegetation community and sediment type combinations (Fig. 2). Sediment particles were exposed to raindrop impact in the clipped to the soil surface treatment. Raindrop energy could have caused detachment of the sediment particles causing movement farther downslope (Mannering and Moldenhauer 1982; Hairsine et al. 1991; Hairsine and Rose 1992; Kinnell 1993). Vegetation protected the sediment particles from direct raindrop impact in the $10 \mathrm{~cm}$ (except the sedge/Sheep Creek sediment combination) and natural height treatments and, therefore, sand particles did not move as far as in the clipped to the soil surface treatment.

\section{Regression Analyses}

Multiple regression analyses of sand movement data provided insights into the erosion process. The variables selected through forward selection processes were \% surface vegetation cover, aboveground biomass, \% shrubs, surface roughness coefficient, and $\%$ silt in the introduced sediment (medium to coarse textured sand movement downslope in $\mathrm{cm}=34.82+9.74 \%$ cover of shrubs $+1.03 \%$ incoming silt $-0.38 \%$ surface vegetation cover 0.18 surface roughness (standard deviation) $-0.04 \mathrm{~g}$ aboveground biomass). The model results indicated that these variables had significant influences on the distance that sand moved downslope $(\mathrm{P}<0.01)$. The model accounted for $62 \%$ of the variation in sand movement within plots $\left(r^{2}=0.62\right)$.

Possible explanations for the variables influence on sand movement are as follows: Decreasing surface cover exposed the sediment to greater raindrop impact and, therefore, increased sand movement through splash erosion (Hairsine et al. 1991). As aboveground biomass decreased, less total vegetation was present to intercept raindrops and protect sand particles from splash erosion. The sand particles were transported farther downslope when shrubs were present. A possible explanation is that shrubs located in the upper region of the plots formed small hummocks. Overland flow was concentrated around the perimeter of the hummocks, thereby increasing overland flow transport capacity through increased flow velocity and depth (Rogers and Schumm 1991).

A reduction in the surface roughness coefficient for plots resulted from a smoother surface, so sediment would not have to fill surface depressions before moving downslope. The positive relationship for percentage of silt in the introduced sediment and the distance sand moved downslope may indicate a reduction in the percentage of larger sand particles in the introduced sediment. Thereby, a greater percentage of smaller, and more readily transported, sediment particles would be present for farther downslope transport.

\section{Experiment 2: Sediment Trap Results}

MANOVA results for sediment collected in the traps indicated the presence of a significant 3-way interaction for sediment particle size class $1(2-10 \mu \mathrm{m})$ for community by sediment type by distance downslope $(P=0.03$ ). Additionally, significant 2-way interactions for sediment trap data were observed for vegetation height by distance downslope $(P=0.01)$ and vegetation community by vegetation height $(P=0.03)$.

Significant differences were found for percentage of particle size class $2(10-30 \mu \mathrm{m})$ present in sediment traps among vegeta- tion communities $(P=0.01)$ and type of introduced sediment $(P<$ 0.01 ). Also, a significant interaction was present for vegetation height by distance downslope $(\mathrm{P}<0.01)$ for particle size class 2 . For particle size class $3(30-50 \mu \mathrm{m})$, significant differences were found only for the 2 sediment types $(P<0.01)$. No significant differences among any of the treatments were found for the larger particle size classes $4(50-100 \mu \mathrm{m})$ and $5(100-200 \mu \mathrm{m})$. A LSD procedure was applied to interaction means to determine where significant differences existed.

\section{Particle Size Class 1 Results}

A greater percentage of particle size class $1(2-10 \mu \mathrm{m})$ particles were present at the 3 distances downslope for the finer silica sediment, when compared with the coarser Sheep Creek sediment that was derived from in-situ soil. This might be expected as the finer silica sediment would be transported a greater distance, with equal overland flow energy, than would the coarser Sheep Creek sediment.

The vegetation height and distance downslope interaction for sediment trap data indicated that for $10 \mathrm{~cm}$ height and natural height vegetation, there was a greater percentage of particle size class 1 particles present at $180 \mathrm{~cm}$ downslope as compared with the $60 \mathrm{~cm}$ downslope position (Fig. 3). There were no significant differences between the 60 and $180 \mathrm{~cm}$ downslope distances in the percent of class 1 particles deposited, when vegetation had been clipped to the soil surface $(0 \mathrm{~cm})$.

Differences observed for particle size class 1 interactions suggested that vegetation cover protected larger particles from raindrop impact and, therefore downslope transport. Sediment might be protected from raindrop impact in taller vegetation, thus sediment transport would be primarily by overland flow processes.

\section{Particle Size Class 2 Results}

A significantly greater percentage of particle size class 2 $(10-30 \mu \mathrm{m})$ was present at 60 and $120 \mathrm{~cm}$ than at $180 \mathrm{~cm}$ downslope when vegetation was clipped to the soil surface. Both the 10 $\mathrm{cm}$ clipping height and natural height vegetation treatments resulted in smaller percentages of particle size class 2 present as distance downslope increased (Fig. 4). Results are consistent with the expected outcome for particle movement; i.e., larger particles

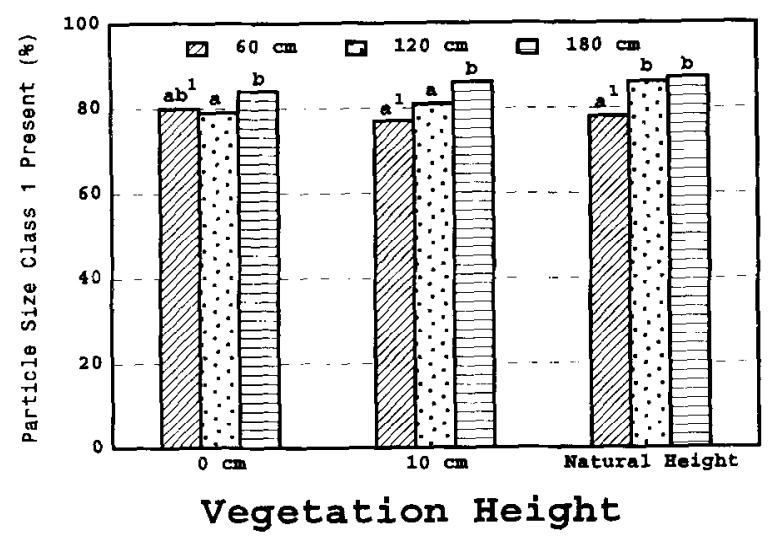

Fig. 3. Interaction between vegetation height and distance downslop for percentage of particle size class 1 present in sediment traps. 'Means in a bar cluster, by vegetation height, with the same letter are not significantly different $(P>\mathbf{0 . 0 5})$. 


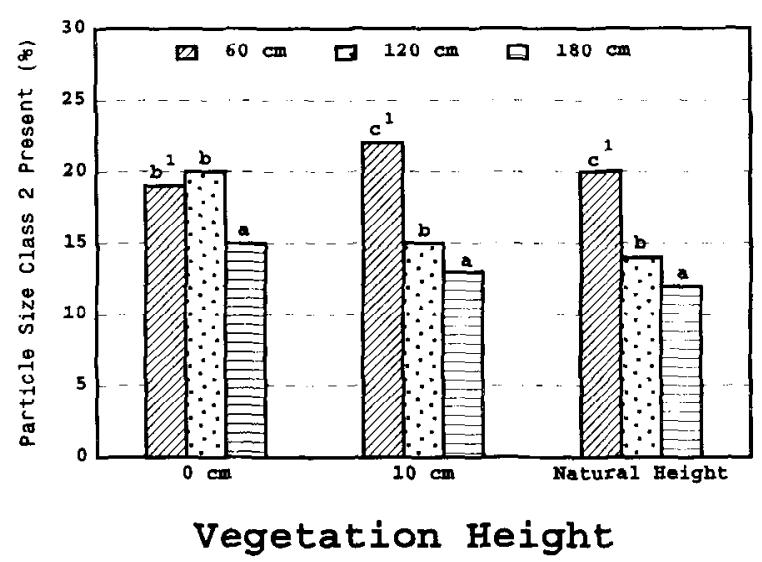

Fig. 4. Interaction between vegetation height and distance downslope for percentage of particle size class 2 present in sediment traps. ${ }^{1}$ Means in a bar cluster, by vegetation height, with the same letter are not significantly different $(\mathrm{P}>\mathbf{0 . 0 5})$.

did not move as far downslope as smaller particles (comparing data for particle size class 2 with class 1 ).

Significant differences existed between the 2 sediment types and 2 vegetation communities for particle size class 2 . Results indicated that a greater percentage of particle size class 2 was present at all distances downslope for the Sheep Creek sediment (mean = $26 \%$ ) when compared with the silica sediment (mean $=7 \%$ ). This would be expected since the Sheep Creek sediment contained a larger percentage of coarse particles than did the silica sediment. A greater percentage of particle size class 2 was present at all distances downslope in the grass complex community (mean $=18 \%$ ) when compared with the sedge community (mean $=16 \%$ ).

\section{Particle Size Classes 3-5 Results}

Interpretation of particle size class differences by distance from the sediment source suggested that there was efficient sediment removal (through insufficient transport capacity of runoff and protection from raindrop impact) of the larger particles (classes 3 through $5 ; 30-200 \mu \mathrm{m})$ among all plots in the first $120 \mathrm{~cm}(2$ rows). Finer particles traveled greater distances downslope before settling out of runoff, as was expected.

\section{Regression Particle Size Class 1}

Multiple regression analysis was applied to the particle size class 1 data and the model yielded an $r^{2}=0.82$ and a $P$ value $<0.01$. Variables selected by forward selection processes were bare ground (\%), sedge spp. (\% of vegetation composition), sand in introduced sediment (\%), grass spp. (\% of vegetation composition), distance downslope $(\mathrm{cm})$, and vegetation density $\left(\right.$ stems $\left.\mathrm{m}^{-2}\right)(\%$ particle class 1 present in sediment traps $=113.7+3.69$ distance downslope -1.13 introduced sand $\%-0.19$ bareground $\%+0.14$ grass spp. $\%+0.12$ sedge spp. $\%+0.01$ vegetation density).

The distance downslope and the percentage of sand in the introduced sediment were the 2 most influential variables selected in the regression model for the percentage of particles present. If the percentage of introduced sand was increased, then the percentage of particle size class 1 present was reduced. Second, as distance downslope increased, the percentage of particle size class 1 present increased. As distance downslope increased, less energy in overland flow in some plots would be available to transport larger sand particles. The reduction in overland flow energy was in some instances caused by infiltration of overland flow as water progressed downslope. All overland flow and rainfall that were applied did not run off in some plots. Therefore, some water infiltrated into the soil before it reached the end of the plot. Also, transport capacity of the overland flow was not sufficient to transport larger particles that would settle out in the upslope portions of the plots (Agarwal and Dickinson 1991). The percentage of bare ground present negatively influenced the percentage of particle size class 1 present. It is assumed therefore, that bare ground contributed particles greater in size than particle size class 1. Both the amounts of grass and sedge present increased the presence of class 1 particles. This suggested that herbaceous vegetation acted as a filter, or protected sediment particles from raindrop impact, for particles greater than $10 \mu \mathrm{m}$ (class 1 size). The same conclusion can be attributed to the positive correlation for stem density. As vegetation density increased, more particles less than $10 \mu \mathrm{m}$ (class 1 size) were present in sediment traps.

\section{Regression Particle Size Class 2}

Multiple regression analysis was also performed on the particle size class 2 data. The resultant $r^{2}$ was 0.85 with a $P$ value $<0.01$. The variables selected through forward selection processes were bare ground (\%), sedge spp. (\% of vegetation composition) distance downslope $(\mathrm{cm})$, clay in introduced sediment (\%), vegetation height $(\mathrm{cm})$, and surface roughness coefficient (standard deviation) (\% particle class 2 present in sediment traps $=93.16-3.50$ distance downslope $-1.86 \%$ introduced clay $+0.14 \%$ bare ground $-0.04 \%$ sedge +0.04 surface roughness coefficient -0.03 vegetation height).

Again, as with particle size class 1 , the distance downslope and the texture of the introduced sediment had the greatest influence on the percentage of particle size class 2 present in sediment traps. The influence of the above 2 variables was reversed for particle size class 2 when compared with particle size class 1 . There was less of particle size class 2 found in the sediment traps the farther the downslope distance. Increased percentage of clay in the introduced sediment resulted in reduced presence of particle size class 2 ; i.e., when a greater percentage of finer particles were available for transport, fewer large particles would be available for transport. Also, the influence of the percentage of bare ground present on particle size class 2 was the opposite as it was for particle size class 1 . The greater the percentage of bare ground present, the greater the percentage of particle size class 2 present. Again, this suggested that bare ground contributed particles larger than $10 \mu \mathrm{m}$ to sediment that was transported. Increased vegetation height and an increased percentage of sedge present both reduced the percentage of particle size class 2 present in sediment traps. This suggested that the presence of vegetation reduced the exposure of particle size class 2 sediment to raindrop impact, and therefore, reduced transport downslope. Increased surface roughness yielded greater presence of particle size class 2 present. This suggested that increased surface roughness was more efficient in removal of smaller particles $(<10 \mu \mathrm{m})$ than it was in reducing transport of particles in the larger class 2 particle size

The differences in variables selected in regression analysis between the particle size class 1 and 2 are in some instances obvious. For example, the percentage of introduced sand in the particle size class 1 was important, while the percentage of introduced 
clay in particle size class 2 was important for sediment movement. If a higher percentage of sand made up the introduced sediment, there would be less silt (2-10 $\mu \mathrm{m}$ range) available for deposition at any distance downslope. Conversely, if a higher percentage of clay made up the introduced sediment, then a smaller percentage of silt $(10-30 \mu \mathrm{m}$ range) would be available for downslope transport.

The positive correlation of percentage of grass and increased vegetation density variables for reducing distance moved by particle size class 1 , and the negative correlation of vegetation height for particle size class 2 are explainable. All 3 of these variables protect larger particles from raindrop impact. Therefore, increased percentage of grass, increased vegetation density, and increased vegetation height might all reduce the presence of larger particles in sediment that is moving. The smaller particles will be transported in overland flow, whereas the larger particles may require additional raindrop impact for continued transport.

\section{Summary and Conclusions}

Information gained from this study was helpful to evaluate the effectiveness of stubble height guidelines for a riparian filter. Results of sediment trap and coarse particle (greater than 200 $\mu \mathrm{m})$ movement data suggested that transport capacity of overland flow in the upper portions of a runoff plot and the ability of raindrops to contact the sediment and thereby displace sediment particles were two important factors that influenced sediment movement. Also, it appeared that vegetation height was relevant only as a component to protect sediment or bare soil surfaces from raindrop impact. Additionally, vegetation height was important in regression models only for sediment particles of size 10 to 30 $\mu \mathrm{m}$.

The results of this study collaborate recent research conducted by Abt et al. (1992, 1993) and Clary et al. (1996). Their study included vegetation height as a factor that might affect sediment filtration. Sediment entrapment was evaluated along a simulated meandering stream in a laboratory using varied heights of Kentucky bluegrass sod to cover the stream bank. Results indicated that vegetated stream banks showed an increase in sediment deposition as compared with bare stream banks.

Our study raised the possibility that vegetation height was important for reducing individual sediment particle detachment and transport in the upper portions of rainfall simulation plots in some instances (i.e., experiment 1 , sand particles and experiment 2 , particle size classes 1 and 2). This may have implications for protection of streambanks where vegetation has been grazed to the soil surface. Vegetation height may help to reduce sediment particles from being detached from streambanks and then being moved into the strcam. However, in terms of overland flow from uplands, it is more important that vegetation cover (both surface and canopy) be maintained to protect the soil surface from rain drop impact and therefore sediment detachment. Increased aboveground biomass, increased vegetation density, or increased vegetation cover reduced coarse sediment particle (primarily $>200$ $\mu \mathrm{m})$ movement downslope and reduced the presence of particles larger than $10 \mu \mathrm{m}$ at all distances downslope. Additionally, results reported in this study were consistent with theoretically predicted particle movement (i.e., smaller particles will be transported farther downslope under equivalent runoff conditions) (Haan et al. 1994).
This study showed that additional variables, besides vegetation height, influenced sediment movement. Land managers should understand that when they manage ecosystems for a single factor, such as vegetation height, they cannot address complex issues such as sediment particle detachment, sediment movement, and sediment filtration. Therefore, stubble height guidelines, such as those implemented by the U.S. Forest Service, may not be the most appropriate measure for management practices in riparian zones.

\section{Literature Cited}

Abt, S.R., W.P. Clary, and C.I. Thornton. 1992. Ability of streambed vegetation to entrap fine sediments. pp. 249-259. In: M.E. Jones and A. Laenen (eds.) Interdisciplinary Approaches in Hydrology and Hydrogeology. Amer. Inst. of Hydrology. Minneapolis, Minn.

Abt, S.R., W.P. Clary, and C.I. Thornton. 1993. Sediment entrapment in vegetated streambeds. pp. 75-91. In: "Preserving Our Environment-The Race Is On." Proceedings: International Erosion Control Assoc., Conference XXIV. Indianapolis, Ind.

Agarwal, A. and W.T. Dickinson. 1991. Effect of texture, flow, and slope on interrill sediment transport. Trans. ASAE 34:1726-1731.

Allen, T. 1990. Particle Size Measurement, 4th Ed. Chapman and Hall, New York, N.Y. 806 p.

Bonham, C.D. 1989. Measurements for Terrestrial Vegetation. John Wiley and Sons, New York, N.Y. 338 p.

Buckhouse, J.C. and R.E. Gaither. 1982. Potential sediment production within vegetative communities in Oregon's Blue Mountains. J. Soil Water Conserv. 37:120-122.

Buckhouse, J.C. and J.L. Mattison. 1980. Potential soil erosion of selected habitat types in the high desert region of central Oregon. J. Range Manage. 33:282-285.

Clary, W.P. and B.F. Webster. 1990. Riparian grazing guidelines for the intermountain region. Rangelands. 4:209-212.

Clary, W.P., C.I. Thornton, and S.R. Abt. 1996. Riparian stubble height and recovery of degraded streambanks. Rangelands. 18:137-140.

Hairsine, P.B., C.J. Moran, and C.W. Rose. 1991. Recent developments regarding the influence of soil surface characteristics on overland flow erosion. Aust. J. Soil Res. 30:249-264.

Hairsine, P.B. and C.W. Rose. 1992. Modeling water erosion due to overland flow using physical principles: 1 . Sheet flow. Water Resour. Res. 28:237-243.

Haan, C.T., B.J. Barfield, and J.C. Hayes. 1994. Design Hydrology and Sedimentology for Small Catchments. Academic Press, San Diego, Calif. $588 \mathrm{p}$.

Hoppe, F.M. 1993. Multiple Comparisons, Selection, and Applications in Biometry. Marcel Dekker, Inc., New York, N.Y.

Johnson, R.A. and D.W. Wichern. 1992. Applied Multivariate Statistical Analysis. Prentice Hall. Englewood Cliffs, N.J. 642 p.

Kauffiman, J.B. and W.C. Krueger. 1984. Livestock impacts on riparian ecosystems and streamside management implications....a review. J. Range Manage. 37:430-437.

Kauffman, J.B., W.C. Krueger, and M. Vavra. 1983. Effects of late season cattle grazing on riparian plant communities. J. Range Manage. $36: 685-690$.

Khan, M.J., E.J. Monke, and G.R. Foster. 1988. Mulch cover and canopy effect on soil loss. Trans. ASAE 31:706-711.

Kinnell, P.I.A. 1993. Sediment concentrations resulting from flow depth/drop size interactions in shallow overland flow. Trans. ASAE 36:1099-1103.

Klute, A. (Ed.) 1986. Methods of Soil Analysis. Part I. Physical and Mineralogical Methods. Amer. Soc. Agron. \& Soil Sci. Soc. Amer. Madison, Wis. 1188 p.

Kondolf, G.M. 1994. Livestock grazing and habitat for a threatened species: land-use decisions under scientific uncertainty in the White Mountains, California, USA. Environ. Manage. 18:501-509. 
Laflen, J.M., W.J. Elliot, J.R. Simanton, C.S. Holzhey, and K.D. Kohl. 1991. WEPP soil erodibility experiments for rangelands and cropland soil. J. Soil and Water Conser. 46:39-44.

Linse, S.J. 1992. The influence of ground cover on upland range erosion. M.S. Thesis. Univ. Wyoning., Laramie, Wyo. 98 p.

Mannering, J.V. and W.C. Moldenhauer. 1982. The effect of raindrop impact and slope length on sediment concentration of runoff. In: Proc., Indiana Acad. of Sci.: The Acad.. Indianapolis, Ind. 92:463-467.

McCalla II, G.R., W.H. Blackburn, and L.B. Merrill. 1984. Effects of livestock grazing on sediment production, Edwards Plateau of Texas. J. Range Manage. 37:291-294.

Noor, M. 1990. Evaluation of ANSWERS model for prediction sediment yield from the riparian zone. Ph.D. Diss., Colo. State Univ., Fort Collins, Colo. 105 p.

Platts, W.S. 1991. Influences of forest and rangeland management on salmonid fishes and their habitats. Amer. Fish. Soc. Spec. Pub. 19:389-423.

Platts, W.S., C. Armour, G.D. Booth, M. Bryant, J.L. Bufford, P. Cuplin, S. Jensen, G.W. Lienkaemper, G.W. Minshall, S.B. Monsen, R.L. Nelson, J.R. Sedell, and J.S. Tuhy. 1987 Methods for evaluating riparian habitats with applications to management. USDAFor. Ser. Gen. Tech. Rep. INT-221. 177 p.

Rinne, J.N. 1990. The utility of stream habitat and biota for identifying potential conflicting forest land uses: montane riparian areas. For. Ecol. Manage. 33/34:363-383.
Rogers, R.D. and S.A. Schumm. 1991. The effect of sparse vegetation cover on erosion and sediment yield. J. Hydrol. 123:19-24.

SAS $^{\circledast}$. 1993. SAS Companion for the Microsoft Windows Environment. SAS Institute Inc. Cary, N.C. 356 p.

Simanton, J.R., M.A. Weltz, and H.D. Larsen. 1991. Rangeland experiments to parameterize the water erosion prediction project model: vegetation canopy effects. J. Range Manage. 44:276-282.

Steel, R.G.D. and J.H. Torrie. 1980. Principles and Procedures of Statistics: A Biometrical Approach. McGraw-Hill, New York, N.Y. $633 \mathrm{p}$.

Storer, D.A. 1984. A simple high volume ashing procedure for determining soil organic matter. Comm. Soil Sci. Plant Anal. 15:759-772.

Thurow, T.L., W.H. Blackburn, and C.A. Taylor, Jr. 1988. Infiltration and interrill erosion responses to selected livestock grazing strategies, Edwards Plateau, Texas. J. Range Manage. 41:296-302.

USDA, Soil Conservation Service and Forest Service. 1980. Soil survey report. Larimer County area, Colorado. Naz 70 soil series. U.S. Govt. Print. Off. 239-812/48. Washington, D.C.

Warren, S.D., T.L. Thurow, W.H. Blackburn, and N.E. Garza. 1986. The influence of livestock trampling under intensive rotation grazing on soil hydrologic characteristics. J. Range Manage. 39:491-495.

Wells II, W.G. and P.M. Wohlgemuth. 1987. Sediment traps for measuring onslope surface sediment movement. USDA-For. Serv.Res. Note. PSW-393. 6 p. 